Arch. histol. jap. Vol. 20, n. 4 (November 1960). P. $599-601$.

2nd. Dept. of Oral Surg. (Director: Prof. K. KAWAKATSU) and 1 st. Dept. of Oral Surg.

(Director: Prof. I. NAGAI), Dental School. Osaka Univ., Joan-cho, Kita-ku, Osaka.

\title{
Histochemical Demonstration of Aminopeptidase Activity in the Developing Teeth of the Rat.*
}

\section{ラットの発青途上歯牙に於ける Aminopeptidase の組織化学的証明について. \\ Masahiko MORI, Wataru YOSHIOKA, Tsuneo MIZUSHIMA and Masaru MURAKAMI.}

\author{
森昌彦, 吉岡済, 水島恒雄, 村上勝.
}

(Received August 14, 1960.)

The colorimetric quantitative test of the aminopeptidase has been introduced by GOMORI (1954), FOLK, BURSTONE (1955), GREEN, TSOU, BRESSLER and SELGMAN (1955). The azo-dye method, adapting L-leucyl- $\beta$-naphthyl amide and DL-alanyl- $\beta$-naphthyl amide as the substrates, was reported by BRUSTONE and FOLK (1955) for the histochemical demonstration of those enzymes. Recently, NACHLAS, CRAWFORD and SELIGMAN (1957) presented their Cu chelating method by employing the same substrate as BURSTONE and FOLK did.

The distribution and localization of aminopeptidase in the tissues were demonstrated by BURSTONE, FOLK (1956) and NACHLAS (1957). The histochemical demonstration of aminopeptidase in the developing tooth and bone is not yet well developed, and there is only a brief information by LIPP (1956) concerning this enzyme activity in the osteocytes. The present report shows the distribution and localization of aminopeptidase in connection with the previous studies on the alkaline, acid phosphatase and esterase in use of the simultaneous coupling azo-dye method, and also on the $\beta$-glucuronidase using the post incubation azo-dye method in the developing tooth of some experimental animals.

\section{Materials and Methods.}

Fetal Wister rats from 20 days old and 5 day new born rats were used. Frozen sections of about $10 \mu$ thick were prepared in the $-20^{\circ} \mathrm{C}$ cryostat according to the LINDERSTRÖM-LANG technique, and the localization of aminopeptidase was studied in use of the methods of BURSTONE, FOLK (1956) and NACHLAS (1957). BCRSTONE used diazotized o-aminoazotoluene (Garnet GBC) and diazotized p-nitroanisidine or p-nitro-p-amino-2.5-dimethoxy-diphenylamine (Black salt $\mathrm{K}$ ). In the present study, however, tetrazotized o-dianisidine (Diazo blue B) was employed instead of Garnet GBC, and the phosphatate buffer at $\mathrm{pH} 6.8$ as the substrate used. L-leucyl- $\beta$-naphthyl amide hydrochloride and DL-alanyl- $\beta$-naphthy amide hydrochloride were used in both methods as the substrates.

* This report was presented at the 14 Congress of Japanese Stomatological Society in May 1960 and the 1st Symposium of Japanese Histochemical Society in July 1960. 


\section{Results.}

The localization of aminopeptidase in the developing tooth and alveolar bone showed a similar appearance in both methods, and the distribution was also the same by using of two kinds of substrates.

This enzyme activity appeared in the basal portion of the dental sac, particularly in the uncalcifying alveolar bone surrounding dental sac, but not at all in the odontoblasts, ameloblasts and calcifying dental tissues. There was also a greater degree of aminopeptidase activity in the stroma of the developing bone, and in the marginal connective tissues of the jaw-bone.

\section{Discussion.}

The enzyme, which participates in the hydrolysis of the peptide compound, is commonly named aminopeptidase, and decompose the various substrates and also separate a amino group from carboxyl group. Biochemical and enzymatic-chemical studies have been made by BERGER and JOHNSON (1940), FRUTON (1946) and SMITH (1948). The pure leucine aminopeptidase is recognized to be specifically reactive on DL-norvalin amide, DL-aminobuthylamide, L-tryptophanamide and Lalaninamide. GOMORI (1954) tested the coloration of the aminopeptidase by using of alanyl- and $\beta$-naphthylamide compounds as the substrates. Since then, the colorimetric determination of aminopeptidase by employing alanyl- $\beta$-naphthyl amide and leucyl- $\beta$-naphthyl amide as the substrates was reported by FOLK (1955) and TSOU, BRESSLER \& SELIGMAN (1955). The histochemical demonstration of aminopeptidase in the organs of normal experimental animals was effected by BURSTON and NACHLAS by applying histochemically these coloration tests, however, this enzyme activity is not yet well known in the developing tooth, bone and calcifying tissue. In the present experiment, the localization of aminopeptidase activity was observed wholly in the dental sac or the basal portion of the pulp except for a part directly in connection with calcification. The distribution and localization in both the leucine and the alanyl substrates were equal each to each. This would suggest that the leucine and the alanyl aminopeptidase are related to the stroma of the dental sac and the pulp, but not directly to calcification.

\section{Summary.}

The histochemical demonstration of aminopeptidase was carried out, by the methods of BURSTONE and NACHLAS. L-leucyl- $\beta$-naphthyl amide and DL-alanyl$\beta$-naphthyl amide hydrochloride were used as the substrates.

1. Aminopeptidase activity in the developing tooth and bone was found in the dental sac and the basal area of the pulp.

2. The odontoblasts, ameloblasts and the tip of the pulp were aminopeptidase negative, and the reduced enamel organ showed only a very slight amount of staining.

3. The localization of aminopeptidase in both leucyl- $\beta$-naphthyl amide and alanyl- $\beta$-naphthyl amide as the substrates was the same, and also BURSTONE and NACHLAS method showed a similar trend in the distribution. 
4. This would suggest that the aminopeptidase is not directly related to calcification.

\section{内 容自抄.}

ラットの発青途上菊牙の aminopeptidase を Burstone ら及び Nachlas の方法に より組織化学的証明を行った。

1. 発㕕途上歯牙及び顎骨における aminopeptidase の局在性は歯囊或いは歯䯚 の基底:部に活性が認められた。

2. 象牙芽紬胞, エナメル芽絒胞及び萪䯣の先端では陰性で, 退縮 エナメル器 に極く僅の活性が認められた。

3. L-leucyl- $\beta$-naphthyl amine と DL-alanyl- $\beta$-naphthyl amine の両基質による aminopeptidaseの分布は同様でままた Burstone 法と Nachlas 法での結果も大体 同椂であった。

4. 以上のことより aminopeptidase は石灰化に直接関係しないという事が示さ れた。

\section{References.}

Berger, J. C. and M. Johnson : The activation of dipeptidase. J. biol. Chem. 133 (1940). P. 639-640. - Burstone, M. S. and J. E. Folk: Histochemical demonstration of aminopeptidase. J. Histochem. Cytochem. 4 (1956). P. 217-226. - Folk, J. E. and M. S. Burstone: Chromogenic leucyl substrates for aminopeptidase and papain. Proc. Soc. exp. Biol. Med. 189 (1955). P. 473-476. - Furton, J. S.: On the proteolytic enzymes of animal tissues. V. Peptidase of skin, lung and serum. J. biol. Chem. 166 (1946). P. 721-738. Gomori, G.: Chromogenic substrate for aminopeptidase. Pro. Soc. exp. Biol Med. 87 (1954). P. 559-561. - Green, M. N., K. C. Tsou, R. Bressler and A. M. Seligman: The colorimetric determination of leucine aminopeptidase activity with L-leucyl- $\beta$-naphthyl amide hydrochloride. Arch. Biochem and Biophys. 57 (1955). P. 458-474. - Lipp, W.: Aminopeptidase in bone cells. (Letters to the Editor.) J. Histochem. Cytochem. 7 (1959). P. 205. Nachlas, M. M., D. T. Crawford and A. M. Seligman : The histochemical demonstration of leucine aminopeptidase. J. Histocehm. Cytochem 5 (1957). P. 264-278. - Smith, E. L.: The peptidases of skeltal, heart, and uterine muscle. J. biol. Chem. 173 (1948). P. 553 569 . 